(c) American Dairy Science Association, 2005.

\title{
Expression of Nuclear Receptor and Target Genes in Liver and Intestine of Neonatal Calves Fed Colostrum and Vitamin A
}

\author{
K. A. Krüger, ${ }^{*}$ J. W. Blum, and D. L. Greger \\ Division of Nutrition and Physiology, Institute of Animal Genetics, Nutrition and Housing, \\ Veterinary Faculty, University of Bern, $\mathrm{CH}-3012$ Bern, Switzerland
}

\begin{abstract}
Nuclear receptors (NR), including retinoic acid and retinoid $\mathrm{X}$ receptors ( $\mathrm{RAR}, \mathrm{RXR})$, pregnane $\mathrm{X}$ receptor (PXR), constitutive androstane receptor, and peroxisome proliferator-activated receptor $(\operatorname{PPAR} \alpha)$ modify the expression of other genes, such as cytochrome $\mathrm{p} 450$ enzymes (CYP), sulfotransferases (SULT), and UDP glucuronosyl transferases (UGT). Nuclear receptor expression is influenced by exposure to ligands (e.g., vita$\min \mathrm{A}$ ). We tested the hypothesis that vitamin A feeding influences the expression of hepatic and intestinal NR and their target genes and that colostrum or formula feeding influence these traits differently. Calves $(n=7 /$ group) were fed colostrum (CO) or a milk-based formula with or without vitamin A (FA, FO, respectively) for 4 $\mathrm{d}$ and were euthanized on $\mathrm{d} 5$, followed immediately by tissue collection. Thereafter, RNA was extracted and gene expression quantified by real-time reverse transcription-polymerase chain reaction. Expression relative to housekeeping genes of mRNA was profiled for NR, CYP, SULT, and UGT enzymes. Hepatic mRNA levels of $\operatorname{RAR} \beta$ and CYP26 were higher in FA than FO cows; expression of CYP2E1, CYP2C8, CYP26, and UGT1A1 was higher in CO than FO cows; and expression of CYP2E1, UGT1A1, and p450 reductase was higher in CO than FA. In colon tissue, abundance of RXR $\alpha$ mRNA was lower in FO than CO, and CYP2B6 expression was lower in FO than in $\mathrm{CO}$ and FA. In jejunal tissue, there were no significant differences in gene expression among groups. In conclusion, effects of vitamin A feeding were limited, but colostrum feeding had several selective effects on expression of nuclear receptors and target genes.
\end{abstract}

(Key words: nuclear receptor, retinoic acid, cytochrome P450, neonatal calves)

Abbreviation key: $\mathbf{C A R}=$ constitutive androstane receptor, $\mathbf{C O}=$ colostrum-fed group, $\mathbf{C Y P}=$ cytochrome

Received June 2, 2005.

Accepted July 7, 2005.

Corresponding author: J. W. Blum; e-mail: blum@itz.unibe.ch.

* Part of a thesis of K.A.K. for Dr. med. vet., submitted 2005 to the Faculty of Veterinary Medicine, University of Bern, Switzerland. p450, FA = formula plus vitamin A-fed group, FO = formula-fed group, LRAT = lecithin: retinol acyltransferase, $\mathbf{N R}=$ nuclear receptor, $\mathbf{P P A R}=$ peroxisome proliferator-activated receptor, $\mathbf{P X R}=$ pregnane $\mathrm{X}$ receptor, $\mathbf{R A}=$ retinoic acid, $\mathbf{R A R}=$ retinoic acid receptor, $\mathbf{R X R}=$ retinoid $\mathrm{X}$ receptor, $\mathbf{S U L T}=$ sulfotransferase, UGT = UDP-glucoronosyl transferase.

\section{INTRODUCTION}

Vitamin A (retinol) is the primary source of retinoids, which include all-trans retinoic acid and 9-cis-retinoic acid. Retinoids are essential nutrients and critical components of a broad array of important physiological processes, which include growth, bone formation, reproduction, immune function, vision, and maintenance of a healthy epithelium, in part through specific interaction with endocrine systems (Franklin et al., 1998). Retinoid function in the embryo begins soon after conception and continues throughout the life span of all vertebrates (Ross et al., 2000). The effects of retinoids are regulated by specific receptors, the retinoid receptors, which are members of a superfamily of nuclear receptors (NR; Evans, 1988). The NR are ligand-activated enhancer proteins that include steroid and thyroid hormone receptors as well as the vitamin D receptor (Riaz-Ul-Haq et al., 1991). The structural organization of the NR molecules is similar, but they show a wide variation in ligand sensitivity (Riaz-Ul-Haq et al., 1991). Generally, $\mathrm{NR}$ contain an $\mathrm{NH}_{2}$-terminal region that has a ligandindependent transcriptional activation function and a core DNA-binding domain. The DNA-binding domain (which contains 2 zinc finger motifs) mediates specific binding to target DNA sequences (ligand response elements), a region that permits protein flexibility to allow for simultaneous receptor dimerization and DNA binding, and a ligand-dependent activation function region (Mangelsdorf and Evans, 1995).

The biological effect of retinoic acid (RA) is thought to be mainly modulated by RA receptors (RAR) and retinoid "X" receptors (RXR; Evans, 1988). All-trans retinoic acid is the ligand for RAR isoforms, and 9-cisRA (which is derived from all-trans retinoic acid) is the ligand for RXR isoforms. These receptors each include 
3 known isoforms ( $\operatorname{RAR} \alpha, \beta, \gamma$ and $\operatorname{RXR} \alpha, \beta, \gamma)$, which are encoded by different genes (Benbrook et al., 1988; Napoli, 1999). The RAR and RXR proteins interact to form homodimers or heterodimers. In addition, other NR such as the constitutive androstane receptor (CAR), pregnane X receptor (PXR), peroxisome proliferatoractivated receptor (PPAR), and several others, may also form functional dimers with RXR. Under physiological conditions, RAR and (or) RXR primarily function as heterodimers with other NR. These heterodimers are capable of binding to $\mathrm{RA}$ response elements within the promoters of responsive genes and activate or repress gene transcription in the presence of retinoids and thereby can regulate a myriad of biological processes (Ross, 2003). These responsive target genes are primarily enzymes needed for metabolism, transport, conjugation, and catabolism of exogenous compounds (xenobiotics) as well as endogenous products of metabolism (endobiotics), such as bile acids. Such genes include cytochrome P450 monoxygenases (CYP), sulfotransferases (SULT), and UDP-glucuronosyl transferases (UGT).

At the time of birth, calves have very low liver reserves of vitamin A, which is reflected by the low concentration of vitamin A in blood (Blum et al., 1997; Swanson et al., 2000; Zanker et al., 2000). To prevent vitamin A deficiency, calves need to ingest high amounts of vitamin A immediately after birth, which is supplied by colostrum. Colostrum usually contains large amounts of $\beta$-carotene, the precursor of retinol (Blum et al., 1997; Zanker et al., 2000). The conversion of $\beta$-carotene to vitamin A occurs in the mucosal cells of the small intestine, but this process in neonatal calves is limited (Nonnecke et al., 2000). Because it is clear that NR play a vital role in the expression of many important enzymes, it is likely that feeding of vitamin A would have major effects on metabolism, health status, and growth performance of young calves. Published studies on NR and NR target genes are very limited in cattle under practical feeding conditions. To the best of our knowledge no studies of this type have been performed in neonatal calves.

The objective of this study was to examine the effects of feeding vitamin A on mRNA expression of genes for $\mathrm{NR}$ and metabolically important NR target genes in liver and the gastrointestinal tract of neonatal calves.

\section{MATERIALS AND METHODS}

\section{Animals, Experimental Procedures, and Evaluation of Health Status}

Twenty-one male calves were selected from a group of 35 calves from a larger study of vitamin A and lactoferrin effects (Muri et al., 2005; Schottstedt et al., 2005).
The calves were born between February and May 2003 at the Experimental Station in Posieux, Switzerland, and at neighboring farms. After parturition they were immediately separated from cows. Three groups of 7 calves each were formed. They were fed either a formula deficient in vitamin A (group FO), a formula supplemented with vitamin A (group FA), or colostrum (group CO). Group FO consisted of 1 Red Holstein calf and 6 Simmental $\times$ Red Holstein calves; group FA consisted of 3 Holstein-Friesian and 4 Simmental $\times$ Red Holstein calves; and group $\mathrm{CO}$ consisted of 3 Holstein-Friesian and 4 Simmental $\times$ Red Holstein calves. In group FA, $351,402,490$, and $490 \mu \mathrm{mol}$ of vitamin $\mathrm{A} / \mathrm{kg}$ of DM were added to the formula that was fed on d 1, 2, 3, and 4 , respectively. The colostrum fed to calves of group $\mathrm{CO}$ contained 49,61 , and $76 \mu \mathrm{mol}$ of vitamin $\mathrm{A} / \mathrm{kg}$ of DM in milkings 1, 2, and 5, respectively, and was collected from cows at the Experimental Station (Posieux, Switzerland). For this purpose, cows were milked twice daily and colostrums of milkings 1,3 , and 5 after parturition were stored separately in plastic bottles at $-20^{\circ} \mathrm{C}$. Formulas or colostrum were warmed to $40^{\circ} \mathrm{C}$ immediately before feeding. Formulas were produced by UFA AG (Sursee, Switzerland) and consisted of calcium caseinate (Emmi Milch AG, Lucerne, Switzerland), lactalbumin (Emmi Milch AG), and a vitamin and mineral premix that supplied the indicated amount of vitamin A (Provimi S.A., Cossonay-Gare, Switzerland). Formula powder was dissolved in water and fat was added during the mixing procedure $(49.7 \%$ saturated fatty acids, $39.0 \%$ unsaturated fatty acids, $6.7 \%$ polyunsaturated fatty acids, $2.1 \%$ trans fatty acids, $2.5 \%$ water; Nutriswiss AG, Lyss, Switzerland). The added fat contained no measurable amounts of vitamin A. Lecithin was added as emulsifier (Emulsifier LO-1; UFA AG) as 3\% of the total fat. Formulas for meals on d 1, 2, 3, and 4 were formulated to contain comparable amounts of nutrients as colostrums fed on d 1 (milking 1), d 2 (milking 3), d 3, and d 4 (milking 5). Compositions of colostrums and formulas, and feed intake data are shown in Tables 1 and 2 , respectively. Pooled mixtures were stored in plastic bottles at $-20^{\circ} \mathrm{C}$ until used. Total fed amounts of formula and colostrum were $6 \% \mathrm{BW}$ on $\mathrm{d} 1,8 \% \mathrm{BW}$ on $\mathrm{d} 2$, and $10 \% \mathrm{BW}$ on $\mathrm{d} 3$ and 4 .

Before the first meal, each calf received a subcutaneous injection of $2 \mathrm{~g}$ of a bovine colostral immunoglobulin preparation (Gammaserin, Gräub AG, Bern, Switzerland) to provide protection against infections. Additionally, calves were fed chicken-egg-derived immunoglobulins that contained high antibody titers against rotavirus and pathogenic Escherichia coli type K99 (Globigen 88; Lohmann Animal Health, Cuxhaven, Germany). Amounts per meal fed were $5,4,3$, and $2 \mathrm{~g}$ on d $1,2,3$, and 4 , respectively. Calves were given a subcutaneous 
Table 1. Composition of colostrum ${ }^{1}$ and formulas ${ }^{2}$ fed to neonatal calves. Values are expressed in kilograms of fresh weight, and per kilograms of DM in parentheses.

\begin{tabular}{|c|c|c|c|c|c|c|}
\hline Parameter & \multicolumn{2}{|c|}{ Day 1} & \multicolumn{2}{|c|}{ Day 2} & \multicolumn{2}{|c|}{ Days 3 and 4} \\
\hline Dry matter, g/kg & 251 & 248 & 164 & 139 & 144 & 127 \\
\hline $\mathrm{CP}, \mathrm{g} / \mathrm{kg}$ & $159(634)$ & $152(613)$ & $77(470)$ & $60(431)$ & $58(403)$ & $48(378)$ \\
\hline Crude fat $\mathrm{g} / \mathrm{kg}$ & $53(211)$ & $59(238)$ & $39(238)$ & $29(209)$ & $36(250)$ & $30(236)$ \\
\hline Nitrogen-free extract, $\mathrm{g} / \mathrm{kg}$ & $27(108)$ & $26(105)$ & $38(232)$ & $45(324)$ & $41(285)$ & $45(354)$ \\
\hline Formula, vitamin A-free & & $\mathrm{NM}^{3}$ & & $\mathrm{ND}^{4}$ & & ND \\
\hline Formula, vitamin A-added & & $87(351)$ & & $56(402)$ & & $62(490)$ \\
\hline
\end{tabular}

${ }^{1}$ Colostrum fed on $\mathrm{d} 1,2$, and 3 and 4 of life were derived from pooled milkings 1,3 , and 5 , respectively.

${ }^{2}$ Formulas fed on d 1, 2, and 3 and 4 of life were composed of calcium-caseinate (97, 238, and $334 \mathrm{~g}$, respectively), lactalbumin (603, 250, and $64 \mathrm{~g}$, respectively), fat (180, 180, and $220 \mathrm{~g}$, respectively), lactose (64, 275, and $322 \mathrm{~g}$, respectively), a vitamin and mineral premix (56, 57 , and $59 \mathrm{~g}$, respectively) and lecithin $(30 \mathrm{~g} / \mathrm{kg})$. Fat per kilogram contained 497, 390, 67, 21, and $25 \mathrm{~g}$ of saturated, unsaturated, polyunsaturated, trans fatty acids, and water, respectively. The mineral premix (per kg) contained $\mathrm{Ca}(186 \mathrm{~g}), \mathrm{Mg}(224 \mathrm{~g}), \mathrm{Na}(31 \mathrm{~g}), \mathrm{P}(92$ g), Cl (48 g), Fe (12 g), Mn (8.1 mg), Cu (1.6 mg), Zn (7.8 mg), I (0.03 mg), Co (0.02 mg), and Se (0.02 mg). Vitamin E contents in colostrum milkings 1,3 , and 5 were 9,6 , and $7 \mathrm{mg} / \mathrm{kg}$, respectively; and in formulas fed on d 1, 2, 3 and 4 were 294,138 , and $97 \mathrm{mg} / \mathrm{kg}$, respectively.

${ }^{3} \mathrm{NM}=$ Not measurable.

${ }^{4} \mathrm{ND}=$ Not determined

injection of antibiotics on $\mathrm{d} 2,3$, and $4(25 \mathrm{mg}$ of enrofloxacin per $10 \mathrm{~kg}$ of BW (Baytril 5\%); Bayer AG, Leverkusen, Germany). Navels were disinfected with betadine (Mundipharma, Basel, Switzerland) shortly after birth. Health status was evaluated daily based on the following clinical traits: rectal temperature, heart rate, respiratory rate, behavior, nasal discharge, respiratory sounds, cough, appetite, fecal consistency, navel, and joint inspection.

Experimental procedures were approved by the Cantonal Committee for the Permission of Animal Experimentation (Granges-Paccot, Canton of Fribourg, Switzerland) and were under the supervision of the Swiss Federal Veterinary Office (Liebefeld-Bern). Procedures were in accordance with Swiss laws on animal protection.

\section{Tissue Sampling}

Calves were euthanized on d 5 using $80 \mathrm{mg}$ of pentobarbital/kg of BW (Eutha 77; Essex Animal Health, Friesoythe, Germany). Livers and gastrointestinal tract were removed immediately; samples were cut and snap-frozen in liquid nitrogen, and stored at $-80^{\circ} \mathrm{C}$.

Blood samples were collected by venipuncture from jugular veins using evacuated tubes on $d 1,2$, and 4 before and at 2 and $4 \mathrm{~h}$ after the first feeding, on $\mathrm{d} 3$ before feeding, and on $\mathrm{d} 5$ before euthanasia to measure vitamin A concentrations. Tubes containing dipotassium-EDTA (1.8 g/L blood) were kept sun-protected on crushed ice until centrifuged at $1000 \times g$ for $20 \mathrm{~min}$. Supernatants were aliquoted and stored at $-20^{\circ} \mathrm{C}$.

Table 2. Total ingested feed for $4 \mathrm{~d}$ of experimentation.

\begin{tabular}{|c|c|c|c|c|c|c|c|c|}
\hline & \multicolumn{2}{|c|}{ Day 1} & \multicolumn{2}{|c|}{ Day 2} & \multicolumn{2}{|c|}{ Days 3 and 4} & \multicolumn{2}{|c|}{ Total ingested feed } \\
\hline Gross energy, MJ/kg of BW & 0.37 & 0.37 & 0.31 & 0.31 & 0.34 & 0.30 & 1.37 & 1.23 \\
\hline $\mathrm{CP}, \mathrm{g} / \mathrm{kg}$ of $\mathrm{BW}$ & 9.55 & 9.12 & 6.16 & 4.80 & 5.80 & 4.80 & 27.3 & 23.5 \\
\hline Crude fat, $\mathrm{g} / \mathrm{kg}$ of BW & 3.18 & 6.54 & 3.12 & 2.32 & 3.60 & 2.99 & 13.5 & 11.9 \\
\hline Colostrum & 0.74 & & 0.80 & & 1.09 & & 3.7 & \\
\hline Formula, vitamin A-free & & $\mathrm{NM}^{1}$ & & $\mathrm{ND}^{2}$ & & ND & & ND \\
\hline Formula, vitamin A-added & & 5.22 & & 4.47 & & 6.22 & & 22.14 \\
\hline
\end{tabular}

${ }^{1} \mathrm{NM}=$ Not measurable.

${ }^{2} \mathrm{ND}=$ Not determined. 


\section{Laboratory Analyses}

Analyses of formulas and colostrum. Samples of colostrum pools from milkings 1, 3, and 5 and formulas for $\mathrm{d} 1,2$, and 3 were lyophilized to determine DM, CP (by Kjeldahl method), crude fat (ether extract), and crude ash (after combustion at $550^{\circ} \mathrm{C}$ ) using standard procedures at the Swiss Federal Research Station (Agroscope, Posieux, ALP, Posieux). Contents of nitrogen-free extract and gross energy were calculated. Vitamin A concentrations in formula powders with supplemented vitamin A (for d 1, d 2, and d 3) and without supplemented vitamin A (for d 1) were analyzed at the Federal Research Station ALP by HPLC (Söderhjelm and Andersson, 1978) and modified (method 13.1.2 and 13.5.4; Methodenbuch III des Verbandes Deutscher Landwirtschaftlicher Untersuchungen und Forschungsanstalten, VDLUFA-Verlag, Ergänzung 1988 and ISO-Methode Nr. 34/SO 1; vitamin A determination by HPLC; May 15, 1986). Contents of vitamins A and E in colostrum were analyzed at the Federal Research Station ALP, Liebefeld-Bern (Buetikofer and Bosset, 1994).

Blood analyses. Plasma retinol concentrations were measured by an HPLC method with diode-array detection at the University of Ghent (Van Merris et al., 2002), adapted for calf plasma analysis. Plasma protein concentration was measured by the Biuret reaction (Muri et al., 2005).

Total RNA extraction. The RNA was extracted from liver, colon, and jejunum samples using total RNA Isolation NucleoSpinRNAII kits (Macherey-Nagel, Düren, Germany). The concentration of total RNA was measured photometrically at an optical density of 260 $\mathrm{nm}$. The integrity and purity of the RNA were verified by photometrical absorption (ratio of optical density at $260 / 280 \mathrm{~nm}$; ideally $>1.9$; acceptable between 1.7 and 2.1). The RNA solution was diluted with nuclease-free water to a working concentration of $100 \mathrm{ng}$ of total $\mathrm{RNA} / \mu \mathrm{L}$ in a final volume of $200 \mu \mathrm{L}$. The concentration was verified 3 times and the working solution was only used if the coefficient of variation was $<5 \%$. The RNA was stored at $-80^{\circ} \mathrm{C}$ until analyzed.

Reverse transcription. One microgram of total RNA from the sample preparation was reverse transcribed with Promega reverse transcription using 10 $\mathrm{m} M$ random hexamer primers according to the instructions of the manufacturer (Promega Corporation, Madison, WI).

Primer design. The primers used for reverse transcription-PCR (Table 3) were derived either from published sequences when available or were designed with Primer-3 software (Rozen and Skaletski, 2000) using bovine expressed sequence tag sequences obtained by
BLAST (Basic Local Alignment Search Tool) analyses using highly homologous human and rodent sequences to probe genes of interest (The Institute for Genomic Research, Rockville, MD). The size of the PCR products was verified by agarose gel electrophoresis. In addition, the PCR products were sequenced in both directions with an ABI 3730 capillary sequencer (Microsynth Ag, Balgach, Switzerland), using the primers that were used for cDNA amplification. Comparisons between the sequenced PCR products and corresponding published sequences were performed by BLAST analyses (Altschul et al., 1990) at NCBI (http://www.ncbi.nlm.nih.gov/BLAST/) and ranged between 84 and 100\% homology with known mammalian sequences.

Real-time reverse transcription-PCR. The PCR quantification was performed with the LightCycler System (Roche Molecular Biochemicals, Rotkreuz, Switzerland) using software package 3.3 (Roche Molecular Biochemicals) and using SYBR Green I. The following general reverse transcription-PCR conditions were used for the amplification: denaturation program $\left(95^{\circ} \mathrm{C}\right.$ for 10 min); a 3-segment amplification and quantification program repeated 36 times (denaturation at $95^{\circ} \mathrm{C}$ for 15 $\mathrm{s}$, annealing at $55^{\circ} \mathrm{C}$ for $5 \mathrm{~s}$, elongation and single fluorescence acquisition at $72^{\circ} \mathrm{C}$ for $4.0 \mathrm{~s}$ per $100 \mathrm{bp}$ ); melting curve program $\left(60\right.$ to $99^{\circ} \mathrm{C}$ with a heating rate of $0.1^{\circ} \mathrm{C} / \mathrm{s}$ and continuous fluorescence measurements); and cooling to $40^{\circ} \mathrm{C}$.

The cDNA amplification for each gene was performed in 2 replicates. Each replicate included 2 pooled samples as an internal positive control and one water control. The internal control was used to correct for interassay variations between runs.

Ubiquitin, glyceraldehyde-phosphate-dehydrogenase, and $\beta$-actin were selected as housekeeping genes to correct for nonspecific changes in mRNA abundance.

The crossing-point values (which ranged between 20 and 23, respectively) for glyceraldehyde-phosphate-dehydrogenase, $\beta$-actin, and ubiquitin in the liver, colon, and jejunum were highly correlated [Pearson's coefficients of correlation $(\mathrm{r})$ ranged from 0.76 to $0.95(P$ $<0.001)$.

PCR efficiency and reproducibility. The PCR efficiency $(E)$ was calculated based on the slope calculated by the LightCycler software 3.3 (Roche Applied Science) using the equation $\mathrm{E}=10$ (-1/slope). To determine the precision and reproducibility of the assays, the intraand interassay coefficients were determined for replicates within each PCR run, and during 3 different PCR runs, respectively.

The calculated PCR efficiency of the NR and their target genes ranged from 1.72 to 2.37 and was therefore close to 2 . Assay variability was estimated based on the deviation of crossing-point values from the crossing- 
Table 3. Forward (for) and reverse (rev) primer sequences $\left(5^{\prime} \rightarrow 3^{\prime}\right){ }^{1}$

\begin{tabular}{|c|c|c|c|c|}
\hline Gene & & Sequence $\left(5^{\prime} \rightarrow 3^{\prime}\right)$ & $\begin{array}{l}\text { Size } \\
\text { (bp) }\end{array}$ & $\begin{array}{l}\text { GenBank } \\
\text { Accession No. }\end{array}$ \\
\hline \multirow[t]{2}{*}{ RAR- $\alpha$} & for & CAA GAC AAA TCC TCC GGC TA & 217 & ВT021634 \\
\hline & rev & TGT TCC GGT CAT TTC TCA CA & & \\
\hline \multirow[t]{2}{*}{ RAR- $\beta$} & for & GCC TCG ACA TCC TGA TTC TC & 282 & DQ114538 \\
\hline & rev & GTG CTT CCA GCA GTG GTT CT & & \\
\hline \multirow[t]{2}{*}{ RXR- $\alpha$} & for & ATT TTC GAC AGG GTG CTG AC & 201 & XM584188 \\
\hline & rev & CTG CTC GGG GTA CTT GTG TT & & \\
\hline \multirow{2}{*}{$\mathrm{RXR}-\beta$} & for & GGC TGG CAA ACG GCT A & 203 & XM614315 \\
\hline & rev & TGG CCA GGC ACT TCT G & & \\
\hline \multirow[t]{2}{*}{ PXR } & for & GAT GAT CAT GTC CGA TGC AG & 381 & AY789647 \\
\hline & rev & AAG ATC TCT TTC CCG CCA TT & & \\
\hline \multirow[t]{2}{*}{ CAR } & for & TCG ATG CAG CTG AGT AAG GA & 272 & AY789649 \\
\hline & rev & AAG GGA GAT CTG GTC CTC CA & & \\
\hline \multirow[t]{2}{*}{ PPAR- $\alpha$} & for & AAT AAC GCG ATT CGT TTT GG & 233 & AF229356 \\
\hline & rev & TCC ATG TCG TGG ATG AGA AA & & \\
\hline \multirow[t]{2}{*}{$\mathrm{CYP} 2 \mathrm{~B} 6^{2}$} & for & CCA AAT GCC ATA CAC AGA CG & 152 & XM580940 \\
\hline & rev & CAG AGC TCA GGA CGG GAT AG & & \\
\hline \multirow[t]{2}{*}{ CYP3A4 } & for & CGT CCC GAA AGG TTC AGT AA & 185 & Y10214 \\
\hline & rev & TTC AGG GGG ATC TGT GTT TC & & \\
\hline \multirow[t]{2}{*}{ CYP2C8 } & for & TAT GGA CTC CTG CTC CTG CT & 177 & AY265992 \\
\hline & rev & CAT ACT GCT GGG GAC AAG GT & & \\
\hline \multirow[t]{2}{*}{ CYP2A6 } & for & CCA CTT TCG ACT GGC TCT TC & 232 & DQ114539 \\
\hline & rev & GAA GTA GGT GGG GTC GAT GA & & \\
\hline \multirow[t]{2}{*}{ CYP2E1 } & for & CAT GAA ATA CCC GGA GGT TG & 226 & AJ001715 \\
\hline & rev & AAT TAC GAC TGT GCC CTT GG & & \\
\hline \multirow[t]{2}{*}{ CYP26 } & for & CGG CCT TAG GAG CTG TGT AG & 195 & DQ114540 \\
\hline & rev & TTT CTG GCC CAT CAG ATT TC & & \\
\hline \multirow{2}{*}{ SULT2B1 } & for & TCT TCA ACT CCA AGG CCA AG & 193 & DQ114541 \\
\hline & rev & ATC CGA ATC CAG CCC TTA AT & & \\
\hline \multirow[t]{2}{*}{ SULT1A1 } & for & TGT CAG AGA GCC CCT GTC TT & 214 & NM177521.2 \\
\hline & rev & GGT AAT AGG AGA CGG CCA CA & & \\
\hline \multirow[t]{2}{*}{ SULT2A1 } & for & TCC TGG GCA AGA AGC TAG AA & 163 & DQ114542 \\
\hline & rev & CAG TCC CCA GTC ACA CCT TT & & \\
\hline \multirow[t]{2}{*}{ UGT1A1 } & for & GTG GCC CAG TAC CTG TCT GT & 223 & DQ115935 \\
\hline & rev & AGC CCG TAT GGG GAA TAA AC & & \\
\hline \multirow[t]{2}{*}{ UGT1A $6^{3}$} & for & TGC TTT GGG CAA AAT ACC TC & 186 & NM174762 \\
\hline & rev & ACG CCA TTG CAT ATT CCT TC & & \\
\hline \multirow[t]{2}{*}{ P450RED } & for & ACG GCC CTC ACC TAC TAC CT & 150 & DQ109574 \\
\hline & rev & CTC AGG TAC AGC TCC TTG AA & & \\
\hline \multirow{2}{*}{ LRAT } & for & GAT CAG AGA AGC GTC CTT GC & 292 & NM_177503 \\
\hline & rev & CAT CCT TGG GCT TAC ATG GT & & \\
\hline \multirow[t]{2}{*}{ GAPDH } & for & GTC TTC ACT ACC ATG GAG AAG G & 196 & U85042 \\
\hline & rev & TCA TGG ATG ACC TTG GCC AG & & \\
\hline \multirow[t]{2}{*}{ Ubiquitin } & for & AGA TCC AGG ATA AGG AAG GCA T & 197 & Z18245 \\
\hline & rev & GCT CCA CCT CCA GGG TGA T & & \\
\hline \multirow[t]{2}{*}{$\beta$-Actin } & for & ATC ACC ATC GGC AAT GAG C & 330 & AY141970 \\
\hline & rev & TGA TCC ACA TCT GCT GGA AG & & \\
\hline
\end{tabular}

${ }^{1}$ Genes: $\operatorname{RAR} \alpha$ and $\beta=$ retinoid acid receptors; $\operatorname{RXR} \alpha$ and $\beta=$ retinoid $\mathrm{X}$ receptors; $\mathrm{PXR}=$ pregnane $\mathrm{X}$ receptor; $\mathrm{CAR}=$ constitutive androstane receptor; $\mathrm{PPAR} \alpha=$ peroxisome proliferator-activated receptor; $\mathrm{CYP}=$ cytochromes; $\mathrm{SULT}$ = sulfotransferases; UGT = UDP-glucoronosyl transferases; P450red = cytochrome P450 reductase; LRAT = lecithin:retinol acyl-transferase; GAPDH = glyceraldehyde-phosphate dehydrogenase.

${ }^{2}$ Also referred to as CYP2B10 or CYP2B22.

${ }^{3}$ Also referred to as UGT1A4.

point mean value, and percentage variation was in the range between 0.69 and $3.35 \%$ and 0.45 and $2.37 \%$, respectively, for intra- and interassay coefficients of variation for all analyses.

\section{Data Evaluation and Statistical Analyses}

Expression data (as means $\pm \mathrm{SE}$ ) were analyzed for normal distribution using the Univariate Procedure of
SAS (SAS Institute, Inc., Cary, NC). Data were transformed (log or square root) where necessary to obtain normal distributions. An ANOVA was performed using the GLM procedure of SAS. The model used was $\mathrm{Y}_{\mathrm{ij}}=$ $\mu+$ group $_{i}+e_{i j}$, where $Y_{i j}=$ measured value, $\mu=$ general mean, group $p_{i}=$ effects of feed type or vitamin A supplementation, and $\mathrm{e}_{\mathrm{ij}}=$ residual error. Calf was the experimental unit. In case of blood, measurements on $d 1$ and d 5 were included in the statistical evaluation. Breed 
was not included in the model because the number of calves for each group $(\mathrm{n}=7)$ was too low and the breed distribution was too heterogeneous to obtain meaningful and reliable results. When the $F$-test was statistically significant $(P<0.05)$, means were separated using the Bonferroni test. Pearson correlation coefficients were calculated using the CORR procedure of SAS to determine associations between the different genes.

\section{RESULTS}

\section{Feeds, Feed Intake, BW, and Health Status}

The first meal after birth occurred within $4.1 \pm 0.4$ $\mathrm{h}$ and the time of the first meal was not significantly different among groups. During the trial, formula-fed calves ingested $51.3 \mathrm{~g}$ of $\mathrm{DM}, 1.2 \mathrm{MJ}$ of gross energy, $23.5 \mathrm{~g}$ of $\mathrm{CP}, 11.9 \mathrm{~g}$ of crude fat, $14.2 \mathrm{~g}$ of nitrogen-free extract, and $1.9 \mathrm{~g}$ of ash per $\mathrm{kg}$ of BW/d. Calves of group FA ingested on average $22.1 \mu \mathrm{mol}$ of vitamin A per $\mathrm{kg}$ of BW/d, whereas those of group FO did not ingest measurable amounts of vitamin A. Colostrum-fed calves ingested on average $56.8 \mathrm{~g}$ of DM, $1.4 \mathrm{MJ}$ of gross energy, $27.3 \mathrm{~g}$ of crude fat, 12.9 of nitrogen-free extract, $3.3 \mathrm{~g}$ of ash, and $3.7 \mu \mathrm{mol}$ of vitamin A (Table 2). Total feed intake was similar in the 3 groups, but for the entire 4-d period, calves of group CO received slightly higher amounts of DM, gross energy, CP, crude fat, and ash, and slightly lower amounts of nitrogen-free extract than did formula-fed calves.

Birth weights of groups $\mathrm{CO}, \mathrm{FO}$, and FA were similar (45.9, 46.3, and $46.6 \mathrm{~kg}$, respectively; mean for all groups: $46.3 \pm 0.4 \mathrm{~kg}$ ) and BW did not differ among treatment groups during the experiment. Rectal temperature increased $(P<0.05)$ similarly in all groups from d 1 (mean: $38.3 \pm 0.2^{\circ} \mathrm{C}$ ) to d 5 (mean: $39.0 \pm 0.1^{\circ} \mathrm{C}$ ).

\section{Preprandial Blood Retinol and Protein Concentrations}

Concentrations of plasma retinol were similar among groups on $d 1$ (data not shown). Plasma retinol concentrations were affected by feeding $(P<0.001)$ and increased $(P<0.001)$ from d 1 to 5 in groups FA and CO, but remained low in group FO. Retinol concentrations on $\mathrm{d} 5$ were higher $(P<0.001)$ in group $\mathrm{FA}$ than in group FO $(0.78 \pm 0.07$ and $0.17 \pm 0.06 \mu \mathrm{mol} / \mathrm{L}$, respectively). Retinol concentration was also higher $(P<0.001)$ in group CO $(1.00 \pm 0.07 \mu \mathrm{mol} / \mathrm{L})$ than in group FO.

Concentrations of total protein in plasma on $\mathrm{d} 1$ of life (before the first meal) were similar (data not shown), but on $\mathrm{d} 5$ of life were higher $(P<0.001)$ in group CO than in groups FA and FO (59.9 $\pm 1.6,45.1 \pm 0.8$, and $47.1 \pm 0.8 \mathrm{~g} / \mathrm{L}$, respectively).

\section{Hepatic mRNA Abundance of NR and NR Target Genes}

The abundance of $\operatorname{RAR} \beta$ mRNA was higher $(P<0.05)$ in group FA than in group FO (Table 4 ), whereas mRNA levels of $\operatorname{RAR} \alpha, \operatorname{RXR} \alpha$, and $\operatorname{RXR} \beta$ were not different among groups. No significant treatment effects were observed for the mRNA abundance of CAR, PXR, and $\operatorname{PPAR} \alpha$.

Abundance of mRNA of CYP2E1 was higher $(P<0.01)$ in group $\mathrm{CO}$ than in groups $\mathrm{FO}$ and FA (Table 5). Levels of mRNA for CYP2C8 were higher $(P<0.05)$ in group $\mathrm{CO}$ than in group FO. Levels of CYP26 mRNA were 32 -fold higher $(P<0.001)$ in group FA than in group FO, and 8-fold higher $(P<0.05)$ in group CO than in group FO. Abundance of $\mathrm{P} 450$ reductase mRNA was higher $(P<0.05)$ in group CO than in group FA. Of the UDP-glucuronosyl transferases, UGT1A1 mRNA abundance was greater $(P<0.05)$ in group $\mathrm{CO}$ than in groups FO and FA. Abundances of mRNA of other cytochromes (CYP2A6, CYP2B6, CYP3A4), sulfotransferases, UGT1A6, and lecithin:retinol acyltransferase (LRAT) were not significantly different among groups.

Effects on mRNA abundance in jejunum and colon. In the jejunum, relative mean mRNA abundances $\left(\times 10^{-7} \%\right.$ of housekeeping gene mRNA abundance) of $\operatorname{RAR} \alpha, \operatorname{RAR} \beta, \operatorname{RXR} \alpha$, and $\operatorname{RXR} \beta(21.26 \pm 5.03,0.33 \pm$ $0.08,11.28 \pm 3.08$, and $2.46 \pm 0.94$, respectively), of CAR and PXR $(0.69 \pm 0.26$ and $3.08 \pm 1.44$, respectively), of CYP2B6, CYP3A4, and UGTA1 (5.60 $\pm 3.64,12.00 \pm$ 4.09 , and $0.023 \pm 0.009$, respectively), and of SULT1A1, SULT2A1, and SULT2B1 (8.25 $\pm 1.93,45.00 \pm 39.86$, and $0.55 \pm 0.11$, respectively) were not different among groups. The mRNA of PPAR $\alpha$, UGT1A6, CYP2C8, CYP2E1, CYP2A6, CYP26, LRAT, and P450 reductase were not detectable in jejunum.

In the colon, $\operatorname{RXR} \alpha$ mRNA relative abundance was higher $(P<0.05)$ in group $\mathrm{CO}$ than in group FO $(19.8$ $\pm 2.9,9.4 \pm 1.3$, and $14.4 \pm 2.7 \times 10^{-7}$ percentage of housekeeping gene mRNA abundance, respectively); RXR $\alpha$ in FA calves was not different than either from the other treatment groups. Mean mRNA levels $\left(\times 10^{-7}\right.$ percentage of housekeeping gene mRNA abundance) of $\operatorname{RAR} \alpha, \operatorname{RAR} \beta$, and $\operatorname{RXR} \beta(21.45 \pm 3.45,0.34$ \pm 0.11 , and $14.55 \pm 2.41$, respectively), and of CAR and PXR $(0.21 \pm 0.06$, and $2.75 \pm 0.66)$ were not different among groups. The expression of CYP2B6 mRNA was higher $(P<0.01)$ in groups $\mathrm{CO}$ and FA than in group FO $\left(7.2 \pm 2.6,3.7 \pm 1.6\right.$, and $1.3 \pm 0.8 \times 10^{-7}$ percentage of housekeeping gene mRNA abundance, respectively). Mean mRNA expressions of CYP3A4, SULT2B1, and UGT1A1 $(1.34 \pm 0.54,1.19 \pm 0.19$, and $0.39 \pm 0.11$, respectively) were similar among groups. The mRNA for PPAR $\alpha$, UGT1A6, CYP2C8, CYP2E1, CYP2A6, 
Table 4. Relative mRNA abundance $( \pm$ SEM) of hepatic retinoid receptors (RXR and RAR), constitutive androstane receptor $(\mathrm{CAR})$, pregnane $\mathrm{X}$ receptor $(\mathrm{PXR})$, and peroxisome proliferator-activated receptor $(\operatorname{PPAR} \alpha)\left(\times 10^{-7}\right.$ percentage of housekeeping gene mRNA abundance) in neonatal calves fed formula (FO), formula plus vitamin A (FA), or colostrum (CO). ${ }^{1}$

\begin{tabular}{lrrrl}
\hline & \multicolumn{3}{c}{ Feeding group } & \\
\cline { 2 - 4 } Gene & \multicolumn{1}{c}{ FO } & \multicolumn{1}{c}{ FA } & CO & $P$-value \\
\hline RAR $\alpha$ & $40.87 \pm 2.05$ & $29.63 \pm 9.62$ & $52.22 \pm 8.10$ & NS \\
RAR $\beta$ & $0.39 \pm 0.05^{\mathrm{b}}$ & $0.85 \pm 0.21^{\mathrm{a}}$ & $0.64 \pm 0.05^{\mathrm{ab}}$ & 0.03 \\
RXR $\alpha$ & $15.08 \pm 3.97$ & $13.24 \pm 1.62$ & $19.08 \pm 2.27$ & NS \\
RXR $\beta$ & $0.95 \pm 0.10$ & $1.19 \pm 0.14$ & $1.14 \pm 0.23$ & NS \\
CAR & $9.78 \pm 3.21$ & $7.29 \pm 3.62$ & $15.61 \pm 4.29$ & NS \\
PXR & $1.14 \pm 0.24$ & $2.09 \pm 0.40$ & $1.98 \pm 0.30$ & NS \\
PPAR $\alpha$ & $20.51 \pm 5.95$ & $9.25 \pm 3.99$ & $37.24 \pm 11.99$ & NS \\
\hline
\end{tabular}

${ }^{\mathrm{a}, \mathrm{b}}$ Means with different superscripts indicate significant differences $(P<0.05)$ among groups; NS $=$ Not significant $(P>0.05)$

${ }^{1}$ Data are means $\pm \mathrm{SE}, \mathrm{n}=7$ per group.

CYP26, SULT1A1, SULT2A1, LRAT, and P450 reductase were not detectable in colon.

Comparisons of mRNA abundance among nuclear receptors and nuclear receptor target genes. The pattern of relative mRNA abundance was different in the liver (CYP2A6 and CYP3A4 > CYP2C8, CYP2E1, SULT1A1, SULT2A1, and UGT1A6 > RAR $\alpha, \operatorname{PPAR} \alpha$, CYP2B6, P450 reductase, and UGT1A1 > RXR $\alpha$, CAR, and LRAT $>\operatorname{RAR} \beta, \operatorname{RXR} \beta$, PXR, CYP26, and SULT2B) and in the colon (RAR $\alpha$ and CYP2B6 $>$ RXR $\alpha$, CYP3A4, SULT2B1, and UGT1A $>\operatorname{RAR} \beta, \operatorname{RXR} \beta, \mathrm{CAR}$, and PXR), and in the jejunum (CYP3A4 and SULT2A1 $>$ RAR $\alpha$, CYP2B6, and SULT1A1 > RXR $\alpha$, and SULT2B1 $>\operatorname{RAR} \beta, \operatorname{RXR} \beta$, CAR, PXR, and UGT1A1).

Correlations of mRNA abundances among NR and NR target genes. There were several very close significant correlations among different genes: CAR was correlated with $\operatorname{RXR} \alpha\left(\mathrm{r}^{2}=0.31 ; P<0.01\right)$, CYP2A6 $\left(\mathrm{r}^{2}=0.65 ; P<0.001\right)$, and LRAT $\left(\mathrm{r}^{2}=0.73 ; P<0.001\right)$; P450 reductase was correlated with $\operatorname{RAR} \alpha\left(r^{2}=0.71\right.$; $P<0.001)$, UGT1A1 $\left(\mathrm{r}^{2}=0.74 ; P<0.001\right)$, LRAT $\left(\mathrm{r}^{2}=\right.$ $0.79 ; P<0.001)$, and CAR $\left(\mathrm{r}^{2}=0.77 ; P<0.001\right) ; \operatorname{PPAR} \alpha$ was correlated with UGT1A1 $\left(\mathrm{r}^{2}=0.71 ; P<0.001\right)$, CYP2A6 $\left(\mathrm{r}^{2}=0.66 ; P<0.001\right)$, CAR $\left(\mathrm{r}^{2}=0.73 ; P<\right.$ $0.001)$, and $\mathrm{P} 450$ reductase $\left(\mathrm{r}^{2}=0.65 ; P<0.001\right)$; and CYP2A6 was correlated with $\operatorname{RAR} \alpha\left(\mathrm{r}^{2}=0.67 ; P<\right.$ 0.001).

\section{DISCUSSION}

In agreement with previous studies (Hadorn et al., 1997), there was a decrease in DM, gross energy, CP,

Table 5. Relative mRNA abundance ( \pm SEM) of hepatic cytochromes (CYP), sulfotransferases (SULT), and UDP-glucorosyl transferases (UGT), cytochrome P450 reductase (P450RED), and lecithin:retinol acyl transferase (LRAT) $\left(\times 10^{-6}\right.$ percentage of housekeeping gene mRNA abundance) in neonatal calves fed formula (FO), formula plus vitamin A (FA), or colostrum (CO). ${ }^{1}$

\begin{tabular}{|c|c|c|c|c|}
\hline \multirow[b]{2}{*}{ Gene } & \multicolumn{3}{|c|}{ Feeding group } & \multirow[b]{2}{*}{$P$-value } \\
\hline & FO & FA & $\mathrm{CO}$ & \\
\hline CYP2A6 & $2554.80 \pm 739.44$ & $1438.70 \pm 487.58$ & $2678.20 \pm 493.71$ & NS \\
\hline CYP2B6 & $0.19 \pm 0.03$ & $0.39 \pm 0.14$ & $0.22 \pm 0.05$ & NS \\
\hline CYP2E1 & $16.89 \pm 5.24^{\mathrm{b}}$ & $22.08 \pm 5.04^{\mathrm{b}}$ & $73.39 \pm 14.77^{\mathrm{a}}$ & 0.0008 \\
\hline CYP2C8 & $15.13 \pm 5.81^{b}$ & $30.11 \pm 7.24^{\mathrm{b}}$ & $95.29 \pm 34.25^{\mathrm{a}}$ & 0.0292 \\
\hline CYP3A4 & $88.01 \pm 18.15$ & $198.88 \pm 73.19$ & $136.66 \pm 18.64$ & NS \\
\hline CYP26 & $0.03 \pm 0.007^{\mathrm{b}}$ & $0.97 \pm 0.39^{\mathrm{a}}$ & $0.25 \pm 0.09^{\mathrm{a}}$ & 0.0002 \\
\hline SULT1A1 & $21.11 \pm 5.00$ & $22.46 \pm 4.55$ & $22.16 \pm 3.54$ & NS \\
\hline SULT2A1 & $11.84 \pm 2.91$ & $20.90 \pm 4.00$ & $15.50 \pm 2.62$ & NS \\
\hline SULT2B1 & $0.05 \pm 0.01$ & $0.06 \pm 0.02$ & $0.07 \pm 0.01$ & NS \\
\hline UGT1A1 & $6.17 \pm 1.96^{\mathrm{b}}$ & $6.11 \pm 1.90^{\mathrm{b}}$ & $17.65 \pm 3.43^{\mathrm{a}}$ & 0.006 \\
\hline UGT1A6 & $48.83 \pm 11.34$ & $46.47 \pm 10.84$ & $60.46 \pm 8.44$ & NS \\
\hline P450RED & $5.89 \pm 1.66^{\mathrm{ab}}$ & $4.62 \pm 1.25^{\mathrm{b}}$ & $14.63 \pm 2.73^{\mathrm{a}}$ & 0.0144 \\
\hline LRAT & $1.02 \pm 0.28$ & $1.81 \pm 0.84$ & $2.60 \pm 0.40$ & NS \\
\hline
\end{tabular}

${ }^{\mathrm{a}, \mathrm{b}}$ Means with uncommon lowercase superscript letters indicate significant differences $(P<0.05)$ among groups; NS $=$ Not significant $(P>0.05)$.

${ }^{1}$ Data are means $\pm \mathrm{SE}, \mathrm{n}=7$ per group. 
crude fat, and ash contents, and an increase in nitrogenfree extract content in colostrum during the first days of lactation. Nutrient compositions of formulas for each day were intended to be similar to those of colostrum, but actual measurements revealed that calves of group CO ingested slightly more DM, CP, crude fat, gross energy, and ash and less nitrogen-free extract than did FO calves. Vitamin A content in colostrum depends on several factors such as $\beta$-carotene and vitamin A intake of the dam, season, day of lactation, and on parity number of the dam. In the present study, pooled colostrum contained amounts of vitamin A that were comparable with those found in these previous studies, and levels declined over time (Konermann and Abou El Fadle, 1966; Franklin et al., 1998; Zanker et al., 2000).

Loose feces in formula-fed calves from d 3 to 5 indicated a mild disturbance of gastrointestinal tract function. However, in our study, there was no indication of gross pathological intestinal changes (Schottstedt et al., 2005), and there were no differences in other health traits among the different groups. Clinical symptoms that would have been typical for vitamin A deficiency (Eaton et al., 1970) were not observed in our calves, likely because the present experiment was too short for the manifestation of such symptoms (Schottstedt et al., 2005).

Plasma concentrations of vitamin A were very low at birth in all groups, in agreement with other studies, which have shown that newborn calves are deficient in vitamin A (Blum et al., 1997; Franklin et al., 1998; Zanker et al., 2000). As expected, plasma retinol concentrations increased after colostrum feeding. Plasma retinol concentrations in calves fed vitamin A with the formula were not different from those in colostrum-fed calves, in spite of the fact that FA calves fed the vitamin A supplemented formula actually received 7-fold higher amounts of vitamin A than that measured in colostrum. The absorption efficiency of vitamin A was likely much greater in $\mathrm{CO}$ than in FA calves. It cannot be excluded, however, that $\beta$-carotene, the retinol precursor which is present in much higher amounts in colostrum than in formulas (Blum et al., 1997; Zanker et al., 2000), may have been absorbed and converted to some extent to retinol, thus contributing to the vitamin A status. Whether colostral $\beta$-carotene actually affected plasma retinol levels is questionable because the impact of $\beta$ carotene on plasma retinol levels in neonatal calves is small, and it takes longer than $4 \mathrm{~d}$ to convert $\beta$-carotene into retinol (Nonnecke et al., 2000). Whether this holds for neonatal calves will have to be investigated in future studies. The concentrations of retinol in plasma remained low in calves fed the formula without vitamin A. Although plasma retinol levels may not mirror hepatic vitamin A stores until reaching a minimum value
(Swanson et al., 2000; Zanker et al., 2000), calves fed the formula without vitamin A appear to be vitamin Adeficient up to d 5 of life.

Although the abundance of mRNA for hepatic RAR $\beta$ in vitamin A-supplemented calves was similar to colostrum-fed calves, among the formula-fed animals, expression of $\operatorname{RAR} \beta$ was lower in the vitamin A-deficient calves (group FO). This has also been observed in rats fed diets deficient in vitamin A, in which the expression of $\operatorname{RAR} \beta$ as well as $\operatorname{RAR} \alpha$ was low, but increased after RA administration (Riaz-Ul-Haq et al., 1991; Wan et al., 1998). Because the RAR $\beta$ protein has a 10 -fold higher affinity for RA than does the RAR $\alpha$ protein (Riaz-UlHaq et al., 1991), $\operatorname{RAR} \beta$ may be more responsive to $\mathrm{RA}$ than $\operatorname{RAR} \alpha$ at concentrations in the physiological range, and might be involved in regulating its own transcription.

In contrast with $\operatorname{RAR} \beta$, expression of $\operatorname{RAR} \alpha$ in calves of the present study was not affected by vitamin A supplementation. Lack of an increase of RAR $\alpha$ in FA calves may be related to the amount of vitamin A administered; that is, these calves were not overdosed. Although the amount of vitamin A fed was approximately 7 times the amount found in colostrum, feeding vitamin A to calves in this experiment did not result in plasma concentrations greater than those observed in colostrum-fed calves.

Both CYP26 and LRAT are known to be responsible for catabolism of all-trans retinoic acid. Profoundly higher mRNA expression of CYP26 was observed in group FA than in group FO and mRNA abundance was also higher in group $\mathrm{CO}$ than in group FO. Expression and activity of CYP26 and LRAT in the liver and lungs of rodents is induced by RA (Ross, 2003). In contrast to the observed effect on CYP26 expression, however, no treatment differences in any of the examined tissues were observed for LRAT mRNA abundance in our calves.

Hepatic CYP2C8 mRNA abundance was greater in group $\mathrm{CO}$ than in group $\mathrm{FO}$. The Cyp2C8 proteins play a significant role in drug metabolism as well as catalyzing the oxidation of endogenous compounds including alltrans retinoic acid (Leo et al., 1989). Previous in vitro studies have shown that CYP2C8 (and CYP3A4) are regulated by PXR and (or) CAR (Gerbal-Chaloin et al., 2001). However, this is not supported in the present study because CYP3A4 mRNA was not affected, in contrast to CYP2C8 mRNA. However, hepatic CYP2E1 mRNA abundance was higher in colostrum-fed than in either of the formula-fed groups. Induction by a large number of small organic molecules including therapeutic agents and toxicants indicate the broad substrate specificity of CYP2E1 (Lieber, 1997). Previous studies have shown that dietary macronutrients (i.e., total pro- 
tein, fat, and carbohydrates, and thus total energy intake) have effects on the activity of drug-metabolizing enzyme systems (Harris et al., 2003). In the present study, amounts of total fat were slightly higher in colostrum than in formulas, and it is likely that there were also differences in the composition of the fatty acids. Dietary fatty acids can modulate receptor-mediated signaling pathways at multiple levels and thereby affect gene expression (Hwang and Rhee, 1999). It is possible that the slightly higher amount of total fat in colostrum and a different composition of fatty acids induced differential expression of CYP2E1 mRNA.

Higher hepatic abundance of mRNA for $\mathrm{P} 450$ reductase (NADPH-cytochrome P450 oxidoreductase) was observed in the colostrum-fed group than in the group fed the formula with added vitamin A. Cytochrome $\mathrm{P} 450$ reductase is an essential component of the microsomal P450 mixed-function oxidase system. It is located in the endoplasmic reticulum and mediates electron transfer from NADPH to the cytochrome P450 (Miller, 2004). Differential expression of $P 450$ reductase in particular could affect posttranslational activity of many proteins. The importance of relatively high hepatic abundance of mRNA for P450 reductase in colostrumfed calves needs further evaluation.

Hepatic UGT1A1 mRNA abundance was higher in the colostrum-fed than formula-fed calves. The UDPglucuronosyl transferase family of proteins, to which UGT1A1 belongs, are phase II biotransformation enzymes located in the endoplasmic reticulum of liver and other tissues (Shelby et al., 2003). It plays a major role in the metabolism and elimination of hydrophobic compounds, including environmental pollutants, drugs, bilirubin, steroid hormones, and thyroid hormones (Burchell et al., 1998). An explanation for higher expression in the colostrum-fed group is not immediately apparent, except that colostrum likely contains many unidentified compounds that may induce UGT expression. No differences in levels of UGT1A6 mRNA due to vitamin A or feeding were observed.

Previous studies have demonstrated significant variation in the activity and relative expression of hepatic genes encoding UGT, SULT, and CYP after different feeding regimens (Harris et al., 2003; Stott et al., 2004). Although there appears to have been an influence of colostrum feeding on hepatic expression of CYP2E1, CYP2C8, CYP26, P450 reductase, and UGT1A1, many other genes $(\operatorname{RXR} \alpha, \operatorname{RXR} \beta, \operatorname{RAR} \alpha, \mathrm{CAR}, \operatorname{PXR}, \operatorname{PPAR} \alpha$, CYP2A6, CYP2B6, CYP3A4, LRAT, SULT1A1, SULT2A1, SULT2B1, SULT1A6, and UGT1A6) were unaffected by vitamin A supplementation or by feeding formula or colostrum.

In contrast to the liver, there were no treatment effects on mRNA abundance in the jejunum. In the colon, there were few treatment effects on expression of NR or target genes with the exception of $\mathrm{RXR} \alpha$ and CYP2B6. Enhanced expression of RXR $\alpha$ in colostrum-fed calves and numerically higher abundance in calves of group FA than in those of group FO suggest that their higher vitamin A status may have been due to one of several causes. Although the expression of CYP2B6 in the jejunum of group FA was more than 10 times higher than in group FO, this was not statistically significant due to very high variability in group FA. Expression of CYP26 or LRAT in the gastrointestinal tract of the calves was not observed. It is possible that the gastrointestinal tract of neonatal calves is insufficiently developed to express these genes. To our knowledge, there have not been any previous studies on expression of LRAT or CYP26 in calves. In the intestine of these calves, PPAR $\alpha$ and many other genes were not detectable. Expression of CYP2E1 has been observed in the small intestine of mice (Zhang et al., 2003), but was not observed in our calves. In rats, despite high levels of expression in the liver, comparatively weak or no expression of PPAR $\alpha$ was observed in the small intestine (Lindell et al., 2003). It is likely that these 5-d-old calves may have been too underdeveloped to express these genes in the intestine. Very little is known about the expression of mRNA for these genes in the gastrointestinal tract of calves and even in older cattle. Nuclear receptor and NR target genes in the small and large intestine may not be responsive to ingested vitamin A in the neonatal calf.

In the present investigation, different levels of mRNA abundance were observed in the various genes investigated. Although expression of the encoded proteins was not evaluated, the relative expression levels were similar to those previously reported. The major hepatic cytochromes in the human include CYP3A4, CYP2A6, CYP2E1, and CYP2C8 (Gerbal-Chaloin et al., 2001; Harris et al., 2003). Of the genes investigated in the present experiment, expression of these cytochromes was also highest.

Several highly significant correlations among the different genes were observed, in particular between CAR and RAR $\alpha$, and CYP2A6 and LRAT. Peroxisome proliferator-activated receptor $\alpha$ also showed highly significant correlations with UGT1A1, CYP2A6, CAR, and P450 reductase. High correlations may be indicative of interactions in expression responses between these genes. For example, although in the present investigation, CAR in calves was not affected by the different treatments, it is known that CAR is activated by a wide range of xenobiotics and endogenous compounds, and that CAR is involved in the regulation of expression of cytochromes $\mathrm{P} 450$ and other genes which encode pro- 
teins that are involved in detoxification (Maglich et al., 2002).

In conclusion, the present study is the first, to our knowledge, to investigate NR and their target genes in neonatal calves under practical feeding conditions. In this study with neonatal calves, vitamin A supplementation induced only a few changes in hepatic and gastrointestinal tract gene expression of NR and their target genes. It is probable that the results obtained reflect a general developmental immaturity with respect to gene expression in the liver and gastrointestinal tract of neonatal calves. Similar studies using older or mature animals may be more likely to elucidate effects of vitamin A status on hepatic and gastrointestinal tract gene expression. However, colostrum feeding did have an important role in regulating the expression of various genes. Importantly, in terms of mRNA abundance, and by inference, the expression of genes involved in many metabolic functions, mRNA profiles in calves fed milkbased formulas with or without vitamin A were different from those in colostrum-fed calves. Based on these results, calves fed with colostrum may be more able to metabolize xenobiotic and endobiotic metabolites compared with calves fed with formula. It is well accepted that the effects of colostrum in calves are very complex (Blum and Baumrucker, 2002). The present data provide new information that indicates that colostrum feeding does have selective effects on NR gene and NR target gene expression in neonatal calves. The obvious differences between colostrum and formula feeding are of interest and may have implications in neonates other than calves; for example, with respect to feeding of human babies that are fed formula rather than milk (and colostrum) from the mother.

\section{ACKNOWLEDGMENTS}

This study was in part supported by Swiss National Science Foundation (grant \# 32-6705.01). We thank Y. Aeby and his staff at Agroscope Posieux-Liebefeld, Switzerland, for putting calves at our disposal, and E. Husman (UFA AG, Sursee, Switzerland) for helping us to develop milk-based formulas. We would also like to thank Claudine Morel, Chantal Philipona, and Yolande Zbinden (Division of Animal Nutrition and Physiology, Veterinary Faculty, University of Bern, Switzerland) for their excellent laboratory work.

\section{REFERENCES}

Altschul, S. F., W. Gish, W. Miller, E. W. Myers, and D. J. Lipman. 1990. Basic local alignment search tool. J. Mol. Biol. 215:403-410.

Benbrook, D., E. Lernhardt, and M. Pfahl. 1988. A new retinoic acid receptor identified from a hepatocellular carcinoma. Nature 333:669-672.
Blum, J. W., and C. R. Baumrucker. 2002. Colostral insulin-like growth factors and related substances: Mammary gland, and neonatal (intestinal and systemic) targets. Domest. Anim. Endocrinol. 23:101-110.

Blum, J. W., U. Hadorn, H. P. Sallmann, and W. Schuep. 1997. Delaying colostrum intake by one day impairs plasma lipid, essential fatty acid, carotene, retinol and alpha-tocopherol status in neonatal calves. J. Nutr. 127:2024-2049.

Buetikofer, U., and J. O. Bosset. 1994. HPLC-Bestimmungsmethoden in der Qualitätskontrolle von Milch und Milchprodukten. Mitt. Geb. Lebensmittelunters Hyg. 85:594-607. [In German]

Burchell, B., C. H. Brierley, G. Monaghan, and D. J. Clarke. 1998. The structure and function of the UDP-glucuronosyltransferase gene family. Adv. Pharmacol. 42:335-338.

Eaton, H. D., J. J. Lucas, S. W. Nielsen, and C. F. Helmboldt. 1970. Association of plasma or liver vitamin A concentrations with the occurrence of parotid duct metaplasia or of ocular papilledema in Holstein male calves. J. Dairy Sci. 53:1775-1779.

Evans, R. M. 1988. The steroid and thyroid hormone receptor superfamily. Science 240:889-895.

Franklin, S. T., C. E. Sorenson, and D. C. Hammell. 1998. Influence of vitamin A supplementation in milk on growth, health, concentrations of vitamins in plasma, and immune parameters of calves. J. Dairy Sci. 81:2623-2632.

Gerbal-Chaloin, S., J. M. Pascussi, L. Pichard-Garcia, M. Daujat, F. Waechter, J. M. Fabre, N. Carrere, and P. Maurel. 2001. Induction of CYP2C genes in human hepatocytes in primary culture. Drug Metab. Dispos. 29:242-251.

Hadorn, U., H. M. Hammon, R. M. Bruckmeier, and J. W. Blum. 1997. Delaying colostrum intake by one day has important effects on metabolic traits and on gastrointestinal and metabolic hormones in neonatal calves. J. Nutr. 127:2011-2023.

Harris, R. Z., G. R. Jang, and S. Tsunoda. 2003. Dietary effects on drug metabolism and transport. Clin. Pharm. 42:1071-1088.

Hwang, D., and S. H. Rhee. 1999. Receptor-mediated signaling pathways: Potential targets of modulation by dietary fatty acids. Am. J. Clin. Nutr. 70:545-556.

Konermann, H., and W. Abou El Fadle. 1966. Zur Bedeutung von Karotin und Vitamin A für die Darmerkrankungen der Saugkälber. Dtsch. Tierarztl. Wochenschr. 73:543-546. [In German]

Leo, M. A., J. M. Lasker, J. L. Raucy, C. I. Kim, M. Black, and C. S. Lieber. 1989. Metabolism of retinol and retinoic acid by human liver cytochrome P450 2C8. Arch. Biochem. Biophys. 269:305312.

Lieber, C. S. 1997. Cytochrome P-450 2E1: Its physiological and pathological role. Physiol. Rev. 77:517-544.

Lindell, M., M. Lang, and H. Lennernas. 2003. Expression of genes encoding for drug metabolising cytochrome P450 enzymes and P-glycoprotein in the rat small intestine; comparison to the liver. Eur. J. Drug Metab. Pharmacokinet. 28:41-48.

Maglich, J. M., C. M. Stoltz, B. Goodwin, D. Hawkins-Brown, J. T. Moore, and S. A. Kliewer. 2002. Nuclear pregnane X receptor and constitutive androstane receptor regulate overlapping but distinct sets of genes involved in xenobiotic detoxification. Mol. Pharmacol. 62:638-646.

Mangelsdorf, D. J., and R. M. Evans. 1995. The RXR heterodimers and orphan receptors. Cell 83:841-850.

Miller, W. L. 2004. P450 oxidoreductase deficiency: A new disorder of steroidogenesis with multiple clinical manifestations. Trends Endocrinol. Metab. 15:311-315.

Muri, C., T. Schottstedt, H. M. Hammon, E. Meyer, and J. W. Blum. 2005. Hematological, metabolic, and endocrine effects of feeding vitamin $\mathrm{A}$ and lactoferrin in neonatal calves. J. Dairy Sci. 88:1062-1077.

Napoli, J. L. 1999. Interactions of retinoid binding proteins and enzymes in retinoid metabolism. Biochim. Biophys. Acta 1440:139-162.

Nonnecke, B. J., R. L. Horst, D. C. Hammell, and S. T. Franklin. 2000. Effects of supplemental vitamin A on retinoic acid concentration in the plasma of preruminant calves. Int. J. Vitam. Res. $70: 278-286$ 
Riaz-Ul-Haq, A., M. Pfahl, and F. Chytil. 1991. Retinoic acid affects the expression of nuclear retinoic acid receptors in tissues of retinol-deficient rats. Proc. Natl. Acad. Sci. USA 88:8272-8276.

Ross, A. C. 2003. Retinoid production and catabolism: Role of diet in regulating retinol esterification and retinoic acid oxidation. Am. Soc. Nutr. Sci. 133:291S-295S.

Ross, S. A., P. J. McCaffrey, U. C. Drager, and L. DeLuca. 2000. Retinoids in embryonal development. Physiol. Rev. 80:10211054.

Rozen, S., and H. J. Skaletsky. 2000. Primer3 on the WWW for general users and for biologist programmers. Pages 365-386 in Bioinformatics Methods and Protocols: Methods in Molecular Biology. S. Krawetz and S. Misener, ed. Humana Press, Totowa, NJ.

Schottstedt, T., C. Muri, C. Morel, C. Philipona, H. M. Hammon, and J. W. Blum. 2005. Effects of feeding vitamin A and lactoferrin on epithelium and lymphoid tissues of intestine of neonatal calves. J. Dairy Sci. 88:1050-1061.

Shelby, M. K., N. J. Cherrington, N. R. Vansell, and C. D. Klaassen. 2003. Tissue mRNA expression of the rat UDP-glucuronosyltransferase gene family. Drug Metab. Dispos. 31:326-333.

Söderhjelm, P., and B. Andersson. 1978. Simultaneous determination of vitamins $\mathrm{A}$ and $\mathrm{E}$ in feeds and foods by reversed phase high pressure liquid chromatography. J. Sci. Food Agric. 29:697-702.
Swanson, K. S., N. R. Merchen, J. W. Erdman, Jr., J. K. Drackley, F. Orias, D. E. Morin, and M. F. Haddad. 2000. Influence of dietary vitamin A content on serum and liver vitamin A concentrations and health in pre-ruminant Holstein calves fed milk replacer. J. Dairy Sci. 83:2027-2036.

Van Merris, V., E. Meyer, K. De Wasch, and C. Burvenich. 2002. Simple quantification of endogenous retinoids in bovine serum by high-performance liquid chromatography-diode-array detection. Anal. Chim. Acta 468:237-244.

Stott, W. T., H. L. Kan, L. G. McFadden, B. R. Sparrow, and B. B. Gollapudi. 2004. Effect of strain and diet upon constitutive and chemically induced activities of several xenobiotic-metabolizing enzymes in rats. Regul. Toxicol. Pharmacol. 39:325-333.

Wan, Y. J., Y. Cai, and T. R. Magee. 1998. Retinoic acid differentially regulates retinoic acid receptor-mediated pathways in the Hep3B cell line. Exp. Cell Res. 238:241-247.

Zanker, I. A., H. M. Hammon, and J. W. Blum. 2000. Beta-carotene, retinol and alpha-tocopherol status in calves fed the first colostrum at $0-2,6-7,12-13$ or $24-25$ hours after birth. Int. J. Vitam. Nutr. Res. 700:305-310.

Zhang, Q. Y., D. Dunbar, and L. S. Kaminsky. 2003. Characterization of mouse small intestinal cytochrome P450 expression. Drug Metab. Dispos. 31:1346-1351. 